\title{
UTILIZATION OF ACRYLAMIDE AND NATURAL POLYSACCHARIDE BASED POLYMERIC NETWORKS IN PH CONTROLLED RELEASE OF 5-AMINO SALICYLIC ACID
}

\author{
KIRAN KUMAR ${ }^{1}$, B. S. KAITH², HEMANT MITTAL *2 \\ ${ }^{\prime}$ Material Science Research Laboratory, National Institute of Technology \\ Hamirpur 177005 (H. P.) India. \\ ${ }^{2}$ Department of Chemistry, National Institute of Technology, Jalandhar (Punjab) India \\ (Received: October 5, 2010 - Accepted: December 20, 2010)
}

\begin{abstract}
In this paper, psyllium (Psy) and acrylamide (AAm) based superabsorbent, synthesized using potassium persulphate (KPS) as an initiator and hexamethylene tetramine (HTMA) as a crosslinker, has been investigated for its swelling behaviour in distilled water as a function of time, temperature and $\mathrm{pH}$. The hydrogel has further been applied for controlled delivery of 5-amino salicylic acid (5-ASA) under different $\mathrm{pH}$ conditions at $37^{\circ} \mathrm{C}$. It has been found to show Fickian type mechanism as the drug release showed diffusion coefficient less than 0.50 for all the $\mathrm{pH}$ conditions. The gel characteristic constant has been found to show 6.9 $\times 10^{-2}, 20.61 \times 10^{-2}$ and $33.4 \times 10^{-2}$ values for $\mathrm{pH} 4.0,7.0$ and 9.2, respectively. The initial diffusion coefficient has been found to show greater values than late diffusion coefficient confirming greater release at the early stages of the drug release than that in the late stages.
\end{abstract}

Keywords: psyllium, acrylamide, 5-amino salicylic acid, drug delivery, superabsorbent

\section{INTRODUCTION}

A great attention has been diverted towards newly developed and powerful drugs. The toxic effects of each drug above the therapeutic range can not be coped-up with our conventional methods like injections and capsules, which ultimately lead to increasing blood drug concentration, reaching peak and then declining in an uncontrolled way. The obedience of the patient with the prescription decides the plasma drug concentration at a particular time.

In order to evade such problem and to achieve more desirable pattern of drug administration, advances in controlled drug delivery were explored. A study revealed the synthesis of acrylic type polymeric systems with degradable ester bonds linked to 5-ASA for controlled release of the drug. ${ }^{1}$ Investigation of the drug release of polymer prodrugs of 5-ASA has been carried-out and it was observed that the release was not only dependent on the property of the polymers but also dependent on the solubility of the prodrugs. ${ }^{2}$ In a study, polyacrylamide-grafted-guar gum was utilized for the controlled release of diltiazen hydrochloride, in the form of tablet. ${ }^{3}$ Poly(acrylic acid-gethylene glycol) hydrogels were prepared for the study of effects of hydrogel composition, polymerization conditions and surrounding environment on theophylline release kinetics and drug transport mechanism. ${ }^{4}$ Effect of surfactants (Twean 60 and Cremophor RH 40) and drug loading (nystatin) on the drug release rate from ethylene vinyl acetate copolymer was investigated. ${ }^{5}$ Choi et al. ${ }^{6}$ synthesized thermosensitive poly( $N$-isopropylacrylamide)-


isopropylacrylamide) initiated ring opening polymerization of $\varepsilon$-caprolactone. The polymer was found to be efficient for sustained drug delivery.

Kim et al. ${ }^{7}$ prepared an ethylene-vinyl acetate (EVA) matrix containing quinupramine for developing a controlled delivery system. A series of copolymers were synthesized using D, L-lactic acid with sebacic acid and formulated into blank and methotrexate (MTX) loaded microspheres by emulsion-solvent evaporation method. The release profile of the encapsulated drug was studied. ${ }^{8}$ Application of a supercritical antisolvent coating process for controlled drug release design was investigated by Wang et al. ${ }^{9}$ Hydrocortisone as the host drug particles and poly(lactide-co-glycolide) [PLGA] as the polymer carrier, were used as the model system for the purpose. Injectable material having advantages of a sol-to-gel transition system and minimal burst release of drug was synthesized from poly(ethylene glycol)-sebacic acid polyester. ${ }^{10}$ $\mathrm{Xu}$ et al. ${ }^{11}$ has developed and studied a novel controlled drug delivery system in which drug release is achieved by electrochemically actuating an array of polymeric valves on a set of drug reservoirs. Heyes et al. ${ }^{12}$ synthesized an alternative poly(ethylene glycol)-lipid conjugates to overcome some of the disadvantages of commonly used PEG-lipids. The properties of these novel PEG-lipids were investigated using SPLP (PEG-stabilized liposomal vesicles encapsulating plasmid DNA) as a model system. Seong et al. ${ }^{13}$ designed biocompatible and thermosensitive poly(organophosphazenes) to achieve local delivery of peptide and protein drugs. In vitro studies were performed for loading and releasing of human growth hormone $(\mathrm{hGH})$ as a model drug.

Psyllium is a natural plant polysaccharide and is used as an Ayurvedic medicine for many centuries. Chemically, psyllium husk is composed of arabinoxylan, ${ }^{14}$ which is complex polysaccharide having linearly joined $\beta$-1,4-linked D-xylopyranose units with side branches of $\alpha$-L-arabinofuranose residues. Polymeric chain might contain 1500-5000 residues. Branching generally occurs either through 2- or 3-substitution or 2- and 3-disubstitution. ${ }^{15}$ The flexible furanose conformations of the side branches have been found to be the sites for water absorption while disubstitution brings about inflexibility in the main chain.

A very little work has been reported on the modification of psyllium for enhancing its end spectrum. Previously, some work has been done on psyllium and functionalized psyllium has been used as flocculants in purification of water ${ }^{16-20}$ In the present study, Psy-cl-poly(AAm) has been investigated for its swelling behaviour as a function of time, temperature and $\mathrm{pH}$ in distilled water. The hydrogel has been studied for its controlled drug (5-ASA) release behaviour at different $\mathrm{pH}$ conditions.

\section{EXPERIMENTAL}

\section{Materials and method}

Psyllium (Sidhpur Sat-Isabgol Factory), acrylamide (LOBA Chemie Pvt. Ltd.), potassium per sulphate (SD Fine) and hexamethylene tetramine (LOBA Chemie Pvt. Ltd.), 5-amino salicylic acid (Merck), pH tablets (SD Fine), were used as received.

$\mathrm{KBr}$ pellets of the samples were prepared in hydraulic press and the FTIR spectra were recorded using Perkin Elmer spectrophotometer, Shimadzu electronic balance (LIBROR AEG-220) was used for weighing purpose. SEMs of the samples were taken on JEOL STEROSCAN 150 MICROSCOPE. X-ray diffraction studies were carried-out on X-ray diffractometer (BRUKER AXS D8 ADVANCE). X-ray diffractions were performed under ambient conditions on Bruker- $\mathrm{D}_{8}$ advance model using $\mathrm{Cu} \mathrm{K} \alpha\left(1.5418^{\circ} \mathrm{A}\right)$ radiation, Ni-filter and scintillation counter as detector at $40 \mathrm{KV}$ and $40 \mathrm{~mA}$ on rotation between $0.5^{\circ}$ or $1.0 \mathrm{~mm}$ of divergent and anti-scattering slit. The small particle size of each sample of Psy-cl-poly(AAm) and psyllium was made and was homogeneously mixed prior to subjecting it for X-ray diffractometry. The sample holder was made of PMMA polymer and consisted of round central cavity. Outer diameter of the holder was $50 \mathrm{~mm}$, central cavity had diameter of $25 \mathrm{~mm}$ which retained the sample of height $1 \mathrm{~mm}$ and the holder height was $8.5 \mathrm{~mm}$. The holder was 
then held in vertical position and the sample was tapped gently. A glass slide was clipped up to the top face of the sample holder first, so as to form a wall of the sample in symmetry to the holder walls. This procedure was repeated until the cavity was filled. Finally, the glass slide was carefully removed without disturbing the sample surface. Powder outside the central cavity was removed with tissue paper. Corundum was the reference to calibrate the instrument.

Preparation of sample

Free radical graft co-polymerization technique has been used for the modification of psyllium with acrylamide in the presence of KPS-HTMA as an initiator-crosslinker system. $1 \mathrm{~g}$ of psyllium was taken in a flask and mixed till uniformity in a known amount of solvent followed with the addition of initiator $\left(0.9 \times 10^{-2} \mathrm{molL}^{-1}\right) .2 .8 \times 10^{-1} \mathrm{molL}^{-1}$ of monomer and crosslinker $\left(4.3 \times 10^{-2}\right.$ molL $^{-1}$ ) were then added to the mixture. The mixture was vigorously stirred till homogeneity of the reaction mixture is attained. ${ }^{21}$

The homopolymer was separated from reaction mixture by washing with acetone with continuous stirring. The polymers were then dried in hot air oven at $50 \square \mathrm{C}$ till constant weight is attained.

\section{Swelling behaviour in distilled water}

The swelling behaviour of the hydrogels in distilled water has been investigated at varied time $(2,4,8,16$ and $24 \mathrm{~h})$, temperature $(25,37,45$ and 50 ${ }^{\circ} \mathrm{C}$ ) and $\mathrm{pH}$ (acidic, neutral and alkaline). $100 \mathrm{mg}$ of the polymer was taken and immersed in excess of solvent. Polymer was taken out after a definite interval, wiped and was weighed immediately. The process was repeated till a constant weight was reached. The percent swelling was reported, using the well known equation: 22

$$
\begin{gathered}
\mathrm{P}_{\mathrm{s}}=\frac{\mathrm{W}_{\mathrm{s}}-\mathrm{W}_{\mathrm{d}}}{--\mathrm{W}_{\mathrm{d}}} \times 100 \\
\text { where } \mathrm{Ws}=\text { weight of swollen gel, } \mathrm{W}_{\mathrm{d}}=\text { weight of dried ge }
\end{gathered}
$$

\section{Drug loading}

Saturated aqueous solution of the drug was prepared and its wavelength for maximum absorption was noted down. $750 \mathrm{mg}$ of the polymeric sample was immersed in $100 \mathrm{ml}$ of drug solution for $24 \mathrm{~h}$. The polymer was then takenout from the solution, wiped off, and was kept for drying. Dried drug-loaded polymer was then washed with distilled water to remove any surface adhered drug molecules and then was studied for drug release kinetics as a function of release time and $\mathrm{pH}$ using UV-VIS spectrophotometer. Release kinetics was studied at 2 hourly time intervals.

\section{Mathematical analysis}

Mathematical modeling of drug release with hydrogel was studied as per the methods reported earlier in the literature. ${ }^{23-27}$ Since the complex models failed to yield a convenient formulae and required techniques using numerical solutions therefore, generalized empirical equation has been used to describe the water uptake through the glassy polymer and drug release from these devices,. The empirical equation used to describe the water uptake which is the weight gain $\left(\mathrm{M}_{\mathrm{s}}\right)$ can be presented as:

$$
\mathrm{M}_{\mathrm{s}}=k \mathrm{t}^{n}
$$

where, ' $k$ ' and ' $n$ ' are constant. ' $n$ ' $=0.5$ revealed the normal Fickian diffusion whereas ' $\mathrm{n}$ ' $=1.0$ signifies Case II diffusion. Non-Fickian or anomalous diffusion is characterized with value of $n$ between 0.5 and $1.0^{28}$ Evaluation of drug release from the swellable polymers can be evaluated from the above power law expression. ${ }^{29}$ Here, $M_{s}$ is replaced with $M_{t} / M_{\infty}$ and the expression is modified as:

$$
\frac{M_{t}}{M_{\infty}}=k^{n}
$$

where, $M_{t} / M_{\infty}$ is the fractional release of drug in time t. ' $k$ ' is the constant which is characteristic of polymer-drug system. ' $n$ ' is the diffusion exponent characteristic of the release mechanism. Value of ' $n$ ' and ' $k$ ' can be evaluated from the slope and intercept of the plot between $\ln \mathrm{M} / \mathrm{M}$ versus $\ln \mathrm{t}$, respectively. This equation can be applied until $60 \%$ of the total drug is released.

\section{Diffusion coefficients}

Analysis of drug release from various hydrogels can be performed by calculating the diffusion coefficients. Diffusion process can be adequately described through Fick's first and second law. Integral diffusion for the cylindrical hydrogel can be given as: ${ }^{30}$

$$
\begin{array}{lr}
\mathrm{M}_{\mathrm{t}} & \mathrm{Dt} \\
----=4 \times \mathrm{---} \\
\mathrm{M}_{\infty} & \pi \mathrm{l}^{2}
\end{array}
$$

where, $M_{t} / M_{\infty}$ is the fractional release, $M_{t}$ is the drug released at time ' $t$ ', and $\mathrm{M}_{\infty}$ is the drug release at equilibrium, $\mathrm{D}$ is the diffusion coefficient and 1 is the thickness of the sample. The average diffusion coefficient $\left(\mathrm{D}_{\mathrm{A}}\right)$ for the 50 $\%$ release of the drug can be calculated by putting $\mathrm{M}_{t} / \mathrm{M}_{\infty}=0.5$ in Eq. 3 , and can be presented as:

$$
0.049 l^{2}
$$

$$
\mathrm{D}_{\mathrm{A}}=\quad \text {-------- }
$$

where, $\mathrm{t}^{1 / 2}$ is the time required for the $50 \%$ release of drug. as: $: 31,32$

Eq. 5 gives the value of late diffusion coefficient and can be calculated



The slope of plot between $\ln \left(1-M_{t} / M_{\infty}\right)$ and time ' $t$ ' can also be used for the evaluation of $\mathrm{D}_{\mathrm{L}}$.

$$
\mathrm{D}_{\mathrm{L}}=\left(\begin{array}{c}
\text { (slope) } l^{2} \\
-------
\end{array}\right)
$$

\section{RESULTS AND DISCUSSION}

\section{Synthesis}

Various reaction parameters such as initiator concentration, amount of solvent, reaction time, reaction temperature, monomer concentration and crosslinker concentration were optimized and the results obtained are shown in Table 1.

\section{Characterization}

\section{FTIR spectroscopy}

FTIR spectrum of psyllium (Fig. 1a) showed broad peaks at $3427.6 \mathrm{~cm}$ (O-H stretching bonded absorption of carbohydrates), $2925.8 \mathrm{~cm}(\mathrm{CH}$ asymmetric stretching), $1378.8 \mathrm{~cm}(\mathrm{CH}, \mathrm{CH}$ and $\mathrm{OH}$ in-plane bending in carbohydrates), $1039.5 \mathrm{~cm}$ (C-O stretching region as_complex bands, resulting from $\mathrm{C}-\mathrm{O}$ and $\mathrm{C}-\mathrm{O}-\mathrm{C}$ stretching vibrations), $897 \mathrm{~cm}$ and $533 \mathrm{~cm}$ (pyranose rings). ${ }^{31}$

Fig. 1b exhibits the FTIR spectrum of Psy-cl-poly(AAm) which showed peaks at $1666.7 \mathrm{~cm}(\mathrm{C}=\mathrm{O}$ stretching of amide $\mathrm{I}$ band $), 1425.4 \mathrm{~cm}$ ( N-H inplane bending of Amide II $\mathrm{k}$ band), $1249.9 \mathrm{~cm}$ (C-N stretching vibrations of Amide III band) and $819.3 \mathrm{~cm}$ (OCN deformations of amide IV band), besides peaks obtained with that of psyllium. ${ }^{21}$ 
J. Chil. Chem. Soc., 55, № 4 (2010)

Table 1: Various optimized reaction parameters for the synthesis of Psy-cl-poly(AAm).

\begin{tabular}{|c|c|c|c|c|c|c|c|c|c|}
\hline S. No. & $\begin{array}{l}\text { Initiator Conc. } \\
\qquad \times 10^{-3}\end{array}$ & $\begin{array}{l}\text { Amt. of } \\
\text { solvent } \\
\text { (ml) }\end{array}$ & $\begin{array}{l}\text { Reaction } \\
\text { time (min) }\end{array}$ & $\begin{array}{c}\text { Reaction } \\
\text { temp. } \\
\left({ }^{\circ} \mathrm{C}\right)\end{array}$ & pH & $\begin{array}{l}\text { Monomer } \\
\text { conc. } \\
\text { mol } / \mathrm{L}\end{array}$ & $\begin{array}{l}\text { Crosslinker } \\
\text { conc. mol/L }\end{array}$ & $\mathbf{P}_{\mathrm{g}}$ & $\mathbf{P}_{\mathrm{s}}$ \\
\hline 1. & 0 & 20 & 120 & 65 & 7 & 0.703 & $1.426 \times 10^{-2}$ & 0 & - \\
\hline 2. & 9.24 & 20 & 120 & 65 & 7 & 0.703 & $1.426 \times 10^{-2}$ & 128 & - \\
\hline 3. & 18.49 & 20 & 120 & 65 & 7 & 0.703 & $1.426 \times 10^{-2}$ & 108 & - \\
\hline 4. & 27.74 & 20 & 120 & 65 & 7 & 0.703 & $1.426 \times 10^{-2}$ & 0 & - \\
\hline 5. & 36.99 & 20 & 120 & 65 & 7 & 0.703 & $1.426 \times 10^{-2}$ & 0 & - \\
\hline 6. & 9.24 & 10 & 120 & 65 & 7 & 0.703 & $1.426 \times 10^{-2}$ & 56 & - \\
\hline 7. & 9.24 & 15 & 120 & 65 & 7 & 0.703 & $1.426 \times 10^{-2}$ & 84 & - \\
\hline 8. & 9.24 & 20 & 120 & 65 & 7 & 0.703 & $1.426 \times 10^{-2}$ & 120 & - \\
\hline 9. & 9.24 & 25 & 120 & 65 & 7 & 0.703 & $1.426 \times 10^{-2}$ & 147 & - \\
\hline 10. & 9.24 & 30 & 120 & 65 & 7 & 0.703 & $1.426 \times 10^{-2}$ & 0 & - \\
\hline 11. & 9.24 & 25 & 30 & 65 & 7 & 0.703 & $1.426 \times 10^{-2}$ & 0 & - \\
\hline 12. & 9.24 & 25 & 60 & 65 & 7 & 0.703 & $1.426 \times 10^{-2}$ & 136 & - \\
\hline 13. & 9.24 & 25 & 90 & 65 & 7 & 0.703 & $1.426 \times 10^{-2}$ & 138 & - \\
\hline 14. & 9.24 & 25 & 120 & 65 & 7 & 0.703 & $1.426 \times 10^{-2}$ & 149 & - \\
\hline 15. & 9.24 & 25 & 150 & 65 & 7 & 0.703 & $1.426 \times 10^{-2}$ & 149 & - \\
\hline 16. & 9.24 & 25 & 120 & 55 & 7 & 0.703 & $1.426 \times 10^{-2}$ & 99 & - \\
\hline 17. & 9.24 & 25 & 120 & 60 & 7 & 0.703 & $1.426 \times 10^{-2}$ & 136 & - \\
\hline 18. & 9.24 & 25 & 120 & 65 & 7 & 0.703 & $1.426 \times 10^{-2}$ & 149 & - \\
\hline 19. & 9.24 & 25 & 120 & 70 & 7 & 0.703 & $1.426 \times 10^{-2}$ & 129 & - \\
\hline 20. & 9.24 & 25 & 120 & 75 & 7 & 0.703 & $1.426 \times 10^{-2}$ & 0 & - \\
\hline 21. & 9.24 & 25 & 120 & 65 & 4 & 0.703 & $1.426 \times 10^{-2}$ & 12 & - \\
\hline 22. & 9.24 & 25 & 120 & 65 & 7 & 0.703 & $1.426 \times 10^{-2}$ & 149 & - \\
\hline 23. & 9.24 & 25 & 120 & 65 & 9 & 0.703 & $1.426 \times 10^{-2}$ & 15 & - \\
\hline 24. & 9.24 & 25 & 120 & 65 & 7 & 0.2812 & $1.426 \times 10^{-2}$ & - & 3900 \\
\hline 25. & 9.24 & 25 & 120 & 65 & 7 & 0.5624 & $1.426 \times 10^{-2}$ & - & 2057 \\
\hline 26. & 9.24 & 25 & 120 & 65 & 7 & 0.844 & $1.426 \times 10^{-2}$ & - & 1520 \\
\hline 27. & 9.24 & 25 & 120 & 65 & 7 & 1.1252 & $1.426 \times 10^{-2}$ & - & 1227 \\
\hline 28. & 9.24 & 25 & 120 & 65 & 7 & 1.4068 & $1.426 \times 10^{-2}$ & - & 925 \\
\hline 29. & 9.24 & 25 & 120 & 65 & 7 & 0.2812 & $1.426 \times 10^{-2}$ & - & 3900 \\
\hline 30. & 9.24 & 25 & 120 & 65 & 7 & 0.2812 & $2.853 \times 10^{-2}$ & - & 3500 \\
\hline 31. & 9.24 & 25 & 120 & 65 & 7 & 0.2812 & $4.279 \times 10^{-2}$ & - & 4216 \\
\hline 32. & 9.24 & 25 & 120 & 65 & 7 & 0.2812 & $5.706 \times 10^{-2}$ & - & 3280 \\
\hline 33. & 9.24 & 25 & 120 & 65 & 7 & 0.2812 & $7.133 \times 10^{-2}$ & - & 3040 \\
\hline
\end{tabular}

where, no. of replications $=03$, weight of Psyllium $=1.0 \mathrm{~g}$



Fig. 1(a): FT-IR of Psyllium

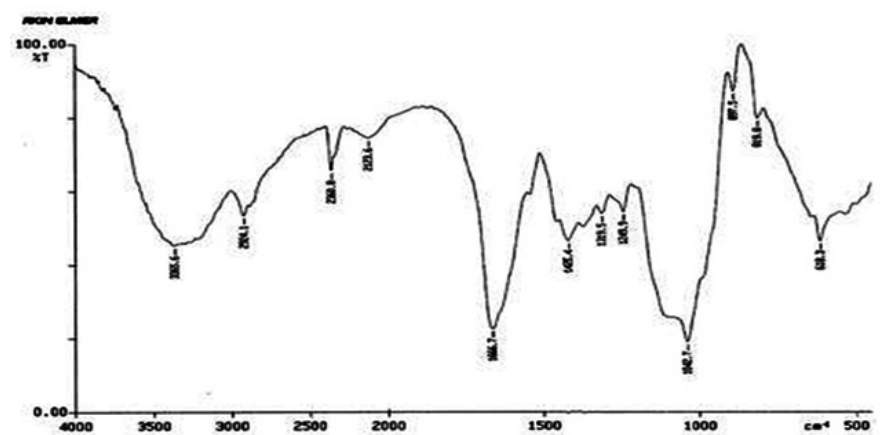

Fig. 1(b): FT-IR of Psy-cl-poly(AAm) 
Scanning electron microscopic studies

In order to have the conducting impact, the gels were gold plated and the scanning was synchronized with microscopic beam so as to maintain the small size over large distance relative to the specimen. The resulting images had a great depth of the field. A remarkable three dimensional appearance with high resolution was obtained in case of backbone and crosslinked samples (Fig. 2).
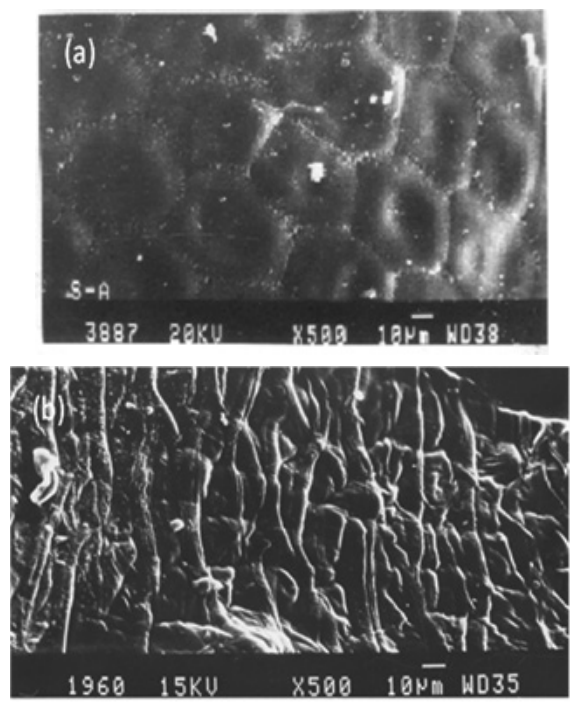

Fig. 2: SEM of (a) Psyllium (b) Psy-cl-poly(AAm)

X-ray diffraction studies

Coherence length (L) of the psyllium and its graft copolymer was calculated using Scherrer equation: ${ }^{32,33}$

$\mathrm{L}=0.9 \lambda / \beta, \mathrm{x} \cos \theta$

where, $\lambda=$ wavelength, $\theta=$ diffraction angle, $L=$ coherence length and $\beta$ $=$ full width half maximum.

It has been found that graft copolymerization of acrylamide onto psyllium resulted in decreased coherence length with increase in graft copolymerization. Hence, there was net decrease in anisotropy of the system with increase in graft yield (Table 2). ${ }^{34}$

Table 2: Effect of concentration of crosslinker on coherence length.

\begin{tabular}{|c|c|c|c|c|}
\hline Sample & $\begin{array}{c}\text { CSL } \\
\left.\text { (molL }^{-1}\right)\end{array}$ & d-spacing & FWHM & $\begin{array}{c}\text { Coherence } \\
\text { Length (nm) }\end{array}$ \\
\hline Psyllium & - & 4.1686 & 6.127 & 2.28 \\
\hline $\begin{array}{c}\text { Psy-cl- } \\
\text { poly(AAm) }\end{array}$ & $\begin{array}{c}4.279 \mathrm{x} \\
10-2\end{array}$ & 2.9286 & 8.329 & 1.74 \\
\hline
\end{tabular}

\section{Swelling behaviour of hydrogel in distilled water}

Effect of time on to $P$

It has been found that the polymer showed increase in percent swelling (P ) with increase in time interval and maximum swelling $(4216 \%)$ was found at $24 \mathrm{~h}$ with $25^{\circ} \mathrm{C}$. However, further increase in time resulted in constant $\mathrm{P}_{\mathrm{s}}$ [Fig. 3a]. This is due to the reason that the porous network of the hydrogel gets completely saturated with the solvent molecules.


Figs. 3(a): Effect of time on $\mathrm{P}_{\mathrm{s}}$; (b) Effect of temperature on $\mathrm{P}_{\mathrm{s}}$
Effect of temperature on to $P$

As is evident from Fig. $3 \mathrm{~b}, \mathrm{P}_{\mathrm{s}}^{\mathrm{s}}$ increases with increase in temperature reaching maximum of $4500 \%$ at $45{ }^{\circ} \mathrm{C}$. Further increase in temperature resulted in decreased $\mathrm{P}$. This can be explained on the basis that with increase in temperature, the network structure initially stretches up to $45^{\circ} \mathrm{C}$ but further rise in temperature resulted in collapse of the network.

Release behaviour of 5-amino salicylic acid

The release of 5-amino salicylic acid through loaded polymeric gels in the medium with different $\mathrm{pH}$ values, was studied at $\lambda_{\max }: 340 \mathrm{~nm}$. The drug release studies have been performed in triplicate and the standard error and standard deviation of these results have been analyzed (Table 3a).

Release of 5-amino salicylic acid with Psy-cl-poly(AAm)-IA-HMTA

As is evident from Fig. 4a, Psy-cl-poly(AAm)-IA has been found to exhibit maximum initial release $(2 \mathrm{~h})$ of drug at $\mathrm{pH} 9.2(218 \pm 6.55 \mathrm{ppm})$ followed by the release at $\mathrm{pH} 7.0(184 \pm 2.08 \mathrm{ppm})$ and release at $4.0 \mathrm{pH}(109 \pm 5.50 \mathrm{ppm})$ Moreover, final release of drug at the interval of $18 \mathrm{~h}$ has also been found maximum in case of alkaline medium $(301 \pm 7.23 \mathrm{ppm})$ followed by release in neutral medium $(291 \pm 7.21 \mathrm{ppm})$ and then in acidic medium $(257 \pm 14.10$ ppm). The drug concentration attained a constant value after $18 \mathrm{~h}$. The release has been found to increase with increase in $\mathrm{pH}$. This is due to the fact that at lower $\mathrm{pH}$, the $-\mathrm{CONH}_{2}$ groups on the backbone are in unionized form, thereby, keeping the polymeric matrix in its collapsed state. But at higher $\mathrm{pH}$ values, these groups get partially ionized to $-\mathrm{COO}^{-}$groups ${ }^{35}$ which being like ionic groups repel each other leading to increased drug diffusion from the polymer matrix. ${ }^{36}$ Fickian type mechanism for the drug release has been observed from the different values of diffusion exponent ' $\mathrm{n}$ ', $0.38,0.25$ and 0.15 at $\mathrm{pH} 4.0$, 7.0 and 9.2 , respectively. The gel characteristic constant ' $\mathrm{k}$ ' has been found to be $6.9 \times 10^{-2}, 20.61 \times 10^{-2}$ and $33.4 \times 10^{-2}$ at $\mathrm{pH} 4.0,7.0$ and 9.2 , respectively (Table 4b). The Fickian type mechanism has further been confirmed from the non-sigmoid curve obtained from the plot of $M_{t} / M_{\infty}$ versus $t^{1 / 2}$ (Fig. $\left.4 \mathrm{~d}\right){ }^{4}$ Mullarney et al ${ }^{37}$ reported similar kind of Fickian behaviour for the release of Pheniramine maleate through

Table 3(a): 5-amino salicylic acid release behaviour of Psy-cl-poly(AAm).

\begin{tabular}{|c|c|c|c|c|}
\hline \multirow{3}{*}{$\begin{array}{c}\text { Time } \\
\text { (h) }\end{array}$} & \multirow{3}{*}{$\begin{array}{c}\text { Sample } \rightarrow \\
\text { pH } \rightarrow\end{array}$} & \multirow{2}{*}{\multicolumn{3}{|c|}{$\begin{array}{c}\text { Psy-cl-poly(AAm) } \\
\text { Drug release at differen } \\
\text { time intervals in } \mathrm{ppm}\end{array}$}} \\
\hline & & & & \\
\hline & & 4.0 & 7.0 & 9.2 \\
\hline \multirow{3}{*}{2} & $\mathrm{M}$ & 109.0 & 184.0 & 218.0 \\
\hline & SE & 5.50 & 2.08 & 6.55 \\
\hline & SD & 9.53 & 3.60 & 11.35 \\
\hline \multirow{3}{*}{4} & $\mathrm{M}$ & 150.0 & 200.0 & 231.0 \\
\hline & $\mathrm{SE}$ & 8.73 & 7.37 & 6.55 \\
\hline & SD & 15.13 & 12.76 & 11.35 \\
\hline \multirow{3}{*}{6} & $\mathrm{M}$ & 182.0 & 216.0 & 243.0 \\
\hline & $\mathrm{SE}$ & 9.45 & 10.11 & 9.64 \\
\hline & SD & 16.37 & 17.52 & 16.70 \\
\hline \multirow{3}{*}{8} & $\mathrm{M}$ & 208.0 & 236.0 & 259.0 \\
\hline & SE & 10.78 & 6.02 & 10.11 \\
\hline & SD & 18.68 & 10.44 & 17.52 \\
\hline \multirow{3}{*}{10} & $\mathrm{M}$ & 216.0 & 249.0 & 268.0 \\
\hline & SE & 7.00 & 5.19 & 10.11 \\
\hline & SD & 12.12 & 9.00 & 17.52 \\
\hline \multirow{3}{*}{12} & $\mathrm{M}$ & 229.0 & 264.0 & 277.0 \\
\hline & SE & 10.44 & 6.02 & 8.32 \\
\hline & SD & 18.08 & 10.44 & 14.42 \\
\hline \multirow{3}{*}{14} & $\mathrm{M}$ & 240.0 & 276.0 & 286.0 \\
\hline & $\mathrm{SE}$ & 5.56 & 11.23 & 9.53 \\
\hline & SD & 9.64 & 19.46 & 16.52 \\
\hline \multirow{3}{*}{16} & $\mathrm{M}$ & 247.0 & 286.0 & 300.0 \\
\hline & SE & 7.23 & 5.50 & 7.21 \\
\hline & SD & 12.53 & 9.53 & 12.49 \\
\hline \multirow{3}{*}{18} & $\mathrm{M}$ & 257.0 & 291.0 & 301.0 \\
\hline & $\mathrm{SE}$ & 14.10 & 7.21 & 7.23 \\
\hline & SD & 24.43 & 12.49 & 12.53 \\
\hline \multirow{3}{*}{20} & $\mathrm{M}$ & 258.0 & -- & -- \\
\hline & $\mathrm{SE}$ & 10.96 & -- & -- \\
\hline & SD & 19.00 & -- & -- \\
\hline \multirow{3}{*}{22} & M & -- & -- & -- \\
\hline & $\mathrm{SE}$ & -- & -- & -- \\
\hline & SD & -- & -- & -- \\
\hline
\end{tabular}

where No. of samples used in each case $=3 ; \mathrm{M}=$ mean; $\mathrm{SE}=$ Standard error of mean; $\mathrm{SD}=$ Standard deviation; -- = constant release 

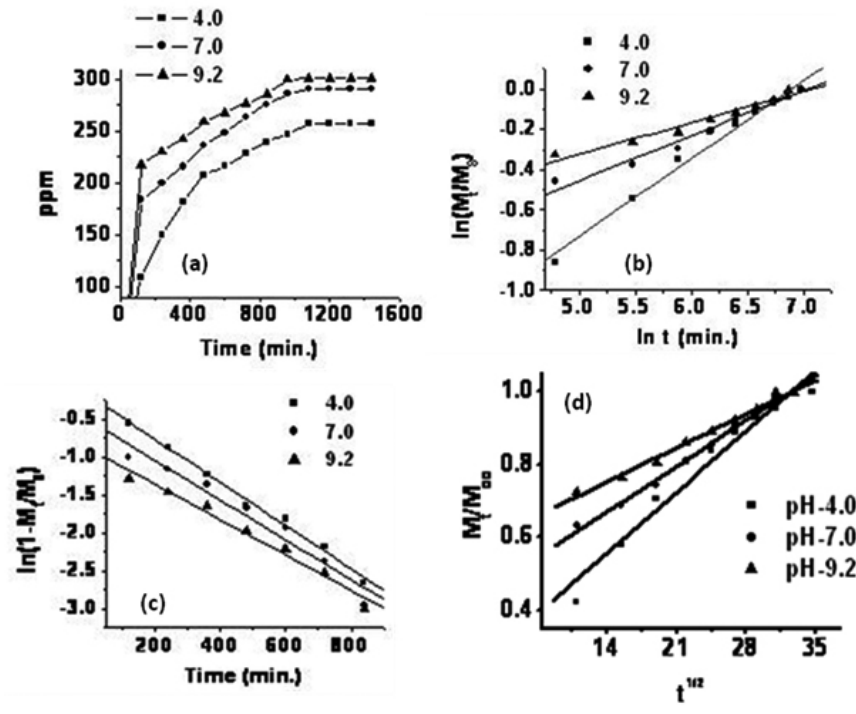

Figs. 4: (a) Effect of pH onto release behaviour of 5-ASA at different time intervals

with Psy-cl-poly(AAm); (b) Plot of $\ln \mathrm{M}_{\mathrm{t}} \mathrm{M}_{\infty}$ versus $\ln \mathrm{t}$ for the release behaviour of Psy-cl-poly(AAm) at $37^{\circ} \mathrm{C}$; (c) Plot of $\ln \left(1-\mathrm{M}_{/} / \mathrm{M}_{\infty}\right)$ versus time for the release behaviour of Psy-cl-poly(AAm) at $37^{\circ} \mathrm{C}$; (d) Plot of $\mathrm{M}_{t} / \mathrm{M}_{\infty}$ versus $\mathrm{t}^{1 / 2}$ for the release behaviour of Psy-cl-poly(AAm) at $37^{\circ} \mathrm{C}$ copolymers of N, N-dimethylacrylamide and 2-(N-ethylperfluorooctanesulfonamido) ethyl acrylate. In another study, similar kind of Fickian type release of drug has been reported by Khorram et al. ${ }^{38}$ using interpenetrating networks of poly $(N-$ isopropylacrylamide) and calcium alginate.

The initial diffusion coefficient at different media has been found to be greater than late diffusion coefficient indicating faster diffusion in the early stages of drug release than the later stage. Further the drug release experiments performed at higher $\mathrm{pH}$ resulted in increased value of 'Di' and ' $\mathrm{D}_{\mathrm{L}}$ ' (Table $3 \mathrm{~b})$. These results manifest the anionic properties and $\mathrm{pH}$ sensitivity of these hydrogels system.

Table 3b: Diffusion exponent, Gel characteristic constant and Diffusion coefficients for the release of 5-Amino salicylic acid through loaded polymer gels.

\begin{tabular}{|c|c|c|c|c|c|c|}
\hline $\begin{array}{l}\text { Sample } \\
\text { Code }\end{array}$ & \multirow{3}{*}{$\begin{array}{l}\mathbf{p H} \\
4.0 \\
\end{array}$} & \multirow{3}{*}{$\begin{array}{c}\text { Diffu- } \\
\text { sion } \\
\text { expo- } \\
\text { nent } \\
\text { 'n' }\end{array}$} & \multirow{3}{*}{$\begin{array}{c}\text { Gel } \\
\text { charac- } \\
\text { teristic } \\
\text { con- } \\
\text { stant } \\
\text { 'k' } \times \\
\mathbf{1 0}^{-2} \\
6.9 \\
\end{array}$} & \multicolumn{3}{|c|}{$\begin{array}{l}\text { Diffusion coefficients } \\
\left(\mathrm{cm}^{2} / \mathrm{min}\right)\end{array}$} \\
\hline \multirow{4}{*}{$\begin{array}{c}\text { Psy-cl- } \\
\text { poly(AAm) }\end{array}$} & & & & & & \\
\hline & & & & 1.1676 & 1.08 & 0.86 \\
\hline & 7.0 & 0.25 & 20.61 & 2.61 & 2.02 & 0.88 \\
\hline & 9.2 & 0.15 & 33.4 & 3.430 & 2.37 & 0.89 \\
\hline
\end{tabular}

where $\mathrm{Di}=$ Initial diffusion coefficient, $\mathrm{D}_{\mathrm{L}}=$ late diffusion coefficient, $\mathrm{D}_{\mathrm{A}}$ $=$ average diffusion coefficient

\section{CONCLUSION}

It can be concluded from the foregone discussion that the functionalized hydrogel i.e. Psy-cl-poly(AAm)-IA-HMTA was found to be $\mathrm{pH}$ and temperature sensitive and hence is a smart polymer. Moreover, the release of 5-ASA at different $\mathrm{pH}$ conditions revealed that the polymer showed controlled $\mathrm{pH}$ sensitive and sustained release. Moreover, Psy-cl-poly(AAm)-IA could withstand the alkaline and acidic conditions in comparison to that of psyllium backbone. Hence, the functionalized polymer is an important candidate for controlled and sustained drug delivery systems.

\section{ACKNOWLEDGEMENT}

We are thankful to Ministry of Human Resource Development, New Delhi for their financial support during the course of the work and the faculty members of Department of Chemistry, Himachal Pradesh University, for their constructive discussion on this work.

\section{REFERENCES}

[1] M. Babazadeh, L. Edjlali, L. Rashidian, J. Polym. Res. 123, 14, (2007).

[2] M. Zou, H. Okamoto, G. Cheng, X. Hao, J. Sun, F. Cui, K. Danjo, Euro. J. Pharm. Biopharm. 59, 155, (2005).

[3] U.S. Toti, M. Aminabhavi, J. Control. Release 95, 567, (2004).

[4] L. Serra, J. Doménech, N.A. Peppas, Biomaterials 27, 5440, (2006).

[5] P. Tallury, M.K. Randall, K.L. Thaw, J.S. Preisser, S. Kalachandra, Dent. Mater. 23, 977, (2007).

[6] C. Choi, S.Y. Chae, J-W. Nah, Polymer 47, 4571, 2006.

[7] J. Kim, W-J. Kim, S-J. Kim, C-W. Cho, S-C. Shin, Intern. J. Pharm. 315, 134, (2006).

[8] S. Modi, J.P. Jain, A.J. Domb, N. Kumar, Euro. J. Pharm. Biopharm. 64, 277, (2006).

[9] Y. Wang, Y. Wang, J. Yang, R. Pfeffer, R. Dave, B. Michniak, Powder Technol. 164, 94, (2006).

[10] J. Lee, M.K. Joo, H. Oh, Y.S. Sohn, B. Jeong, Polymer 47, 3760, (2006).

[11] H. Xu, C. Wang, J. Zoval, M. Madou, Biosens. Bioelectron. 21, 2094, (2006).

[12] J. Heyes, K. Hall, V. Tailor, R. Lenz, I. MacLachlan, J. Control. Release $112,280,(2006)$.

[13] J-Y. Seong, Y.J. Jun, B.M. Kim, Y.M. Park, Y.S. Sohn, Inter. J. Pharm. $314,90,(2006)$.

[14] M.S. Izydorczyk, CG. Biliaderis, Carbohydr. Polym. 28, 33, (1995).

[15] G. Dervilly- Pinel, V. Tran, L. Saulnier, Carbohydr. Polym. 55, 171, (2004)

[16] A., Mishra, A. Yadav, M. Agarwal, R. Srinivasan, Chinese J. Polym. Sci. $22,1,(2004)$

[17] A. Mishra, M. Bajpai, J. hazard. Mater. 118, 213, (2005).

[18] A. Mishra, R. Srinivasan, R. Dubey, Macromol. Mater. Eng. 287, 592, (2002).

[19] A. Mishra, R. Srinivasan, M. Bajpai R. Dubey, Colloid. Polym. Sci. 282, 722, (2004).

[20] A. Mishra, R. Srinivasan, M. Agarwal, R. Dubey, Polym. Bull. 48, 439, (2002).

[21] B.S. Kaith, K. Kumar, Express Polym. Lett. 1, 474, (2007).

[22] G.S. Chauhan, L.K. Guleria, S. Mahajan, Desalination 141, 325, (2001).

[23] M. Bamba, F. Puisieus, J.P. Marty, J.T. Carstensen, Int. J. Pharma. 3, 87, (1979).

[24] L. Brannon-Peppas, N.A. Peppas, J. Control. Release 8, 267, (1989).

[25] R.E. Korsmeyer, V. Meerwall, N.A. Peppas, J. Polym. Sci. Pol. Phys. 24, 409, (1986).

[26] P.I. Lee, J. Membrane Sci. 7, 255, (1980).

[27] N.A. Peppas, R. Gurny, E. Doelker, P. Buri, J. Membrane Sci. 7, 241, (1980).

[28] T. Alfrey, E.F. Gurnee, W.G. Lloyd, J. Polym. Sci. Part C 12, 249, (1966).

[29] P.L. Ritger, N.A. Peppas, J. Control. Release 5, 23, (1987).

[30] P.L. Ritger, N.A. Peppas, J. Control. Release 5, 37, (1987).

[31] B. Singh, S. Kumar, Nucl. Instrum. Math. A 266, 3417, (2008). [32] A.L. Patteron, Phys. Rev. 56, 978, (1939).

[33] H. Malik N. Gupta, A. Sarkar, Mat. Sci. Eng. C-Bio. S, 20, 215, (2002).

[34] B.S. Kaith, R. Jindal, H. Mittal, Der Chemica Sinica, 1, 92, (2010).

[35] T. Kissel, Z. Brich, S. Bantle, I. Lancranjan, F. Nimmerfall, P. Vitt, J. Control Release, 16, 27, (1991).

[36] B. Singh, N. Sharma, N. Chauhan, Carbohydr. Polym. 69, 631, (2007).

[37] M.P. Mullarney, T.A.P. Seery, R.A., Weiss, Polymer 47, 3845, (2006).

[38] M. Khorram, E. Vasheghani-Farahani, N.G. Ebrahimi, Iran. Polym. J. 12, $315,(2003)$. 